\title{
Exploring the Effect of Covid-19 on Cooperative Financial Institutions in Bali
}

\author{
Surya Dewi Rustariyuni ${ }^{1, *}$, M.Pudjihardjo ${ }^{2}$, M.Umar Burhan ${ }^{3}$, Dias Satria $^{4}$ \\ ${ }^{1}$ Department of Economics, Faculty of Business and Economics, Udayana University, Indonesia \\ ${ }^{2,3,4}$ Department of Economics, Faculty of Business and Economics, Brawijaya University, Indonesia \\ ${ }^{*}$ Corresponding author. Email: dewirustariyuni@unud.ac.id
}

\begin{abstract}
One impact of the Covid-19 outbreak has been to freeze economic actors, including cooperative financial institutions. This has prompted researchers to investigate the effects of the pandemic on cooperative financial institutions, the majority of whose members are small and medium sized enterprises, and the ways in which cooperative financial institutions have handled this pandemic situation. This research was conducted using qualitative and quantitative methods, by integrating the TechnologyOrganization-Environment (TOE) framework and the Unified Theory of Acceptance and Use of Technology (UTAUT). Starting with semi-structured questions addressed to managers of cooperative financial institutions, a quantitative study was then carried out, ending with conclusions and recommendations. The preliminary findings of this study are that cooperative financial institutions that adopt digital technology are more likely to survive in the pandemic era, and that the cooperative financial institutions' adoption of technology during this pandemic has been influenced by top management support, ability to cover costs, broadband availability, performance expectations, hedonic motivation, and innovation. The results of exploratory research will be more accurate if they are not limited to geographic boundaries and integrate other popular technology adoption theories. This study first describes the challenges faced by cooperative financial institutions due to the pandemic, then presents how managers of cooperative financial institutions have faced the impact of the crisis.
\end{abstract}

Keywords: cooperative financial institutions, innovation, the Covid-19 pandemic, exploratory research

\section{INTRODUCTION}

Covid-19, declared as a pandemic by the World Health Organization (WHO), has forced the whole world to lock down, thus destroying the production and practice of business (Kumar \& Kalse, 2021). This is the impact resulting from the recommendations issued by the World Health Organization (2020) on protocols to prevent the transmission of Covid-19, such as by detecting and isolating cases, contact tracing and quarantine, and social and physical distancing (at least one meter separation). Following the recommendations of the WHO, many countries have adopted a strict mechanism of prevention, including appropriate cleanliness, frequent hand washing, the wearing of a mask and gloves for self protection, and the implementation of cough ethics (de Caro et al., 2020). Covid-19 has had an impact on the major economies on the world, from the closure of schools, travel restrictions on tourists, the cancellation of public meetings, the closure of cinemas, up to the termination of air travel (Fernandes, 2020). The findings of Shereen et al., (2020) explain that Covid-19 impacts Gross National Products, fiscal and monetary policy and jobs, causing serious social and economic consequences.

The impact of Covid-19 on small businesses is reflected in the findings of Bartik et al., (2020), namely mass layoffs, business closures, and the financial fragility of small businesses. The Global Pulse Survey, which was conducted by the Consultative Group to Assist the Poor (CGAP) on microfinance institutions during the Covid-19 pandemic, explains the decline in the portfolio of loans, the decrease in the liquidity of microfinance institutions (MFIs), the closure of branches, the dismissal of employees, MFIs' implementation of digital channels, and even the expansion and increase of digital channels to customers by some MFIs (Zetterli, 2020). Of the Small and Medium sized Enterprises (SMEs) in Norbotten, for example, almost 80 percent were directly or indirectly affected by Covid 19 and, with demand decreasing, 60 percent experienced cash flow problems (Larsson \& Gustavsson, 2020).

The Covid-19 crisis has drawn attention to many problems, thus triggering a double crisis, as well as causing an economic crisis by damaging many economic activities (Zaazou \& Abdou, 2020). Estimates made by the World Bank indicate that the Covid-19 crisis could push 40 to 60 million people into poverty (Janssens et al., 2021). Another impact caused by the Covid-19 pandemic is seen in the findings of Zheng and Zhang (2021), which show a decrease in the efficiency of financial MFIs. The catastrophic global Covid-19 pandemic threatens the entire continuity of the life of SMEs globally and nationally, because the pandemic has created such a business environment that it is difficult for SMEs to operate, causing an economic crisis which is driven by the policies of governments throughout the whole world, causing a decrease in household 
consumption and thereby causing a decrease in production (Larsson \& Gustavsson, 2020).

Studies by the Ministry of Finance of the Republic of Indonesia on the impact of Covid-19 reveal the threat of loss of household income, inability to work to meet the needs of a minimum standard of living, and the inability of Micro, Small and Medium sized Enterprises (SMEs) to do business, thus leading to the disruption of the ability to meet the needs of credit (Santoso \& Laoli, 2020). Other findings show that the impact of the Covid-19 pandemic on the financial institutions which are engaged in financial services has greatly affected the operations of the agencies. The Covid-19 pandemic has deconstructed the financial institution system that has been operating so far. This phenomenon has caused several financial institutions to close Automated Teller Machines (ATMs), close operational units, limit operating hours, reorganize employee attendance (split operations) in such a way as to provide opportunities for some employees to stay at home in order to reduce operational risk in terms of minimizing the risk of spreading Covid-19, and increase operational costs by providing hand sanitizers, disinfectants, and masks (Rustam, 2020).

It is reported that cooperatives in Indonesia have had difficulty operating. The members of the cooperative are not able to pay the installments and many members withdraw their savings from the cooperative, which has a serious impact on liquidity and the cash flow of the cooperative. The prolonged Covid-19 pandemic has led financial agencies, including cooperatives, to change their patterns of service to adjust to the new habits to be able to survive. The application of technology to cooperatives' financial services has become a necessity to the operation of cooperative services in the era of the Covid-19 pandemic, especially as it is unclear when it will end. The phenomenon of the Covid-19 pandemic must be circumvented by financial institutions to prevent mass transmission of Covid-19 by optimizing the use of digital applications to boost transactions (Ridwansah, 2020).

The Covid-19 pandemic has had a significant impact on all aspects of the life of society, both economic, social, and cultural. Bali is not the only one experiencing this challenge. The rest of the world is also facing the same difficulties. Growth in the economy of Bali in the first quarter of 2020 was minus 1.14 percent, while in the second quarter of 2020 Bali's economy declined by 10.98 percent. This slow growth was caused by a sharp decline in revenue from Bali's main sector, namely tourism. The number of foreign tourists in Bali decreased after the start of the pandemic, falling by as much as 99.97 percent in May 2020. Bali has been experiencing a loss of around 9.7 trillion Rupiah every month from the tourism sector alone. Based on data from the Department of Manpower and Mineral Resources of Bali Province, as of $25^{\text {th }}$ May 2020, as many as 71,313 workers in the formal employment sector had been laid off and 2,570 people had lost their jobs (Baliprov, 2020).

Cooperatives, as one of the motors driving the populist economy, have high resistance in the face of various situational challenges, as well as performing an important social function, which has run well in Bali. It has been well proven that the cooperative was able to maintain its business in the middle of the impact of the Covid-19 pandemic. Some cooperatives have even been able to provide assistance to their members and to the public to ease the burden on the economic community (the Bali Provincial Government, 2020). Bali has 5,016 cooperatives that are spread through nine districts/cities, while the number of SMEs registered is as many as 327,310 , with a percentage growth of 4 percent in 2019. When compared with the number of inhabitants of Bali, currently recorded as 4,230,051, the ratio of entrepreneurship in Bali is relatively small, namely 7.71 percent. In the midst of the Covid-19 pandemic, cooperatives in Bali are facing three serious problems, namely: (1) related to liquidity, when cooperative customers withdraw deposits/savings from cooperatives in large quantities, the cooperative will have liquidity difficulties; (2) cooperative members find it difficult to repay loans, thus interfering with the cooperative's income; and (3) there is the difficulty of paying the loan back to the bank. It is not only cooperatives but also SMEs who are facing a difficult situation. The problems faced by SMEs include constraints on the supply of raw materials due to a number of regions implementing Large-Scale Social Restrictions (PSBB), declining demand due to customers reducing orders, and difficulties in obtaining capital loans. For this reason, the Head of the Bali Province Office for Cooperatives and Micro, Small and Medium sized Enterprises (UMKM) I Wayan Mardiana urges cooperatives and MSMEs to adjust to the life of the new normal era and to digitalization (Rohmat, 2020).

The implementation of technology based financial services by cooperatives in Bali initially served as a financial service to increase the ability of institutions to provide services and to improve the productivity of the institution, but in the era of the Covid-19 pandemic, these financial services have enhanced their capabilities in order to remain able to provide services during this pandemic. Related to this situation was the result of in-depth interviews with 20 managers/chairmen of the board of cooperatives, who stated that it is very important for cooperatives that have not adopted the technology to open a mindset which recognises that the application of financial services using technology is essential in order to be able to provide services in the future facing the Covid-19 pandemic. Indirectly, this indeed motivates a cooperative to adopt the technology in its operational services.

Prior to the outbreak of the Covid-19 pandemic, as many as 154 cooperatives in Bali had already applied technology and information-based financial services. These were initially designed to increase the ability of institutions to provide services and improve the productivity of the institution. Since the onset of the Covid-19 pandemic, the capability of these financial services has been enhanced in order to remain able to provide services during the pandemic. The number of cooperatives that improved their institution's ability to participate in the financial service cooperative after the outbreak of the Covid-19 pandemic totalled 17 cooperatives, which comprised 5 cooperatives in 2019, 9 in 2020 and 3 in 
2021. As can be seen in Figure 1, as many as 172 cooperatives in Bali implemented financial services with semi-online, online, or digital technology clusters, out of 6,996 cooperatives that existed in Bali in 2019.

Figure 1. Application of Cooperative Technology in Bali

\section{Application Period}

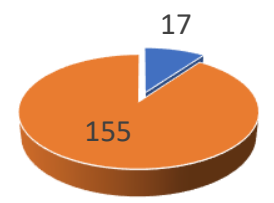

- Before Covid-19 - After Covid-19

Source : Data Processed by Researcher, 2021

As shown in Figure 2, 133 cooperatives in Bali implemented financial services with semi-online, on-line, or digital technology clusters out of 4,090 active cooperatives that existed in Bali in the year 2020. The data shows that the development of financial service cooperatives in Bali using online and digital technology is very low. Digitization of cooperatives can be developed in Bali, in accordance with the switch to digital requirements, due to the fact that the necessary infrastructure and human resources (HR) in Bali are very well-prepared.

Figure 2. Development of Technology Application in Cooperatives in Bali over the last 10 years

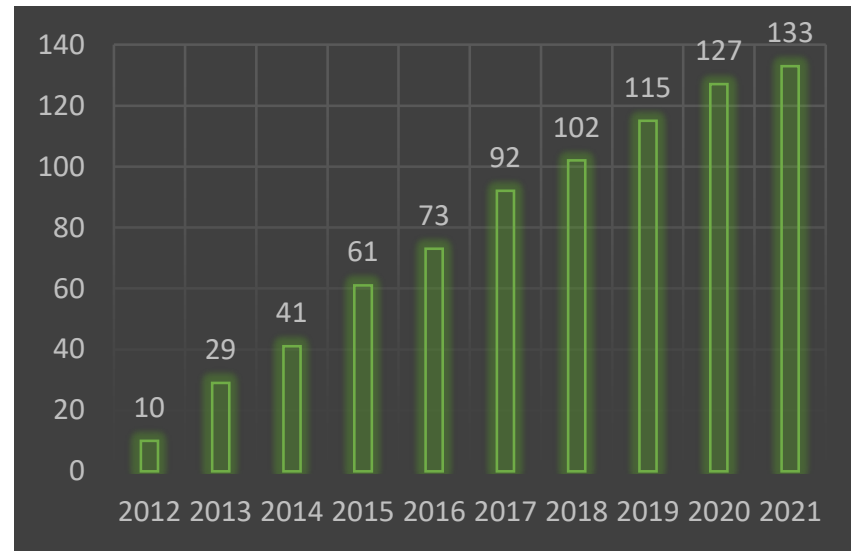

Source : Online Data Processed by Researcher, 2021

For cooperatives, digital services bring benefits for the efficiency of the transaction process, direct engagement among the members of cooperatives, access to additional revenue, and as a way to lure additional markets, especially attracting the interest of the community in making transactions through cooperatives (Nusabali.com, 2020), particularly during the current Covid 19 pandemic. This is also supported by the fact that in 2020 Bali's productive-age population entered an era of demographic bonus, making up $70.96 \%$ of the island's total 4.32 million inhabitants (Wiratmini, 2021). Moreover, broadband in Bali also supports cooperative financial services using technology. Based on this situation, the formulation of the research problem is: What factors influence the cooperative to keep surviving in the face of the Covid-19 pandemic? The aim of the research therefore is to identify factors that affect cooperatives' ability to survive in the face of the Covid-19 pandemic.

\section{LITERATURE REVIEW}

Cooperatives are business institutions that have a comparative advantage, which lies in their members, who are the main assets and whose existence is highly valuable to the cooperatives. This is because cooperatives are established by, from, and for their members so that each cooperative is owned by all the members of that cooperative. For this reason, cooperatives need to retain their members by paying attention to the services they provide to them, based on the concept of maintaining good relationships between the cooperatives and their members. Cooperative members must receive rights to services, to ensure member satisfaction in their business activities and to meet the various needs of the members. Such services must always be improved so that members voluntarily want to actively participate in their cooperative. Member satisfaction is a top priority in accordance with the basic principles of cooperatives, namely from and for members. Cooperatives as business entities are measured by their ability to develop and dominate the market and provide rational alternatives to the needs of members through various incentives and services. Therefore, the quality of service in cooperatives is always seen from the perspective of members because it is the members who determine the value of service quality (Tanjung, 2017; 133-134).

The modernization of cooperatives is guided by the times in the era of economic disruption, digital economics, and economic sharing. The business world has entered industrial revolution 4.0, so cooperatives must be independent and have the ability to compete with other business actors. For this reason, cooperatives must make changes by carrying out digital transformations to enable them to increase their competitiveness with other financial institutions (Alhusain, 2017: 58). The satisfaction of the members will foster their loyalty to the cooperative and can encourage them to actively promote it. By providing optimal services, cooperatives are expected to help improve the economic welfare of their members. Given the importance of service in cooperatives, every effort made by the cooperatives must have a comparative advantage dimension by taking into account the technological-organizational and environmental aspects.

Previous studies have discussed technology adoption in companies using the Technology-Organization-Environment (TOE) framework. The technological context is determined by integrating the Unified Theory of Acceptance and Use of Technology (UTAUT) framework. These studies resulted in a wide range of findings, as follows: (1) performance expectations: some research findings indicate a positive effect (Kováríková et al., 2017), other researchers have found a 
negative effect (Addy et al., 2018) while others (Le et al., 2021) state that there was no effect; (2) hedonic motivation: some researchers found that this had a positive effect (Addy et al., 2018), while Awa, Ojiabo et al. (2017) and Kováríková et al. (2017) state that there was no effect; and (3) in terms of business prospects, some research findings indicate a positive effect (Addy et al., 2018), others a negative effect (Zuiderwijk et al., 2015) while Ayaz \& Yanartaş (2020) and Ooi et al. (2018) found that it had no effect at all. Other technological contexts are: (4) perceived benefits: some research findings indicate that these have a positive effect (Hoque et al., 2016; Osakwe et al., 2015), while the findings of Lian et al. (2014) show no effect.

Previous studies that discussed the organizational framework by integrating the TOE framework, include: (1) top management support: several research findings indicate that this had a positive effect (Asiaei \& Nor, 2019; Awa, Ojiabo, et al., 2017; Qalati et al., 2021), some showed that it had a negative effect (Alkhater et al., 2018) while subsequent research results pointed out that it had no effect (Gutierrez et al., 2015; Ooi et al., 2018); (2) in terms of cost, some research findings indicate that this has a positive effect (Maduku et al., 2016; Sivathanu, 2019), some researchers' findings show that it has a negative result (Ghobakhloo \& Ching, 2019) while the findings of other researchers showed that it has no effect (Ghobakhloo et al., 2011; Ilin et al., 2017); and (3) in terms of innovation, some researchers' findings indicated that this had a positive effect (El-Haddadeh, 2020; Huesig \& Endres, 2019), while other researchers' results show that it had a negative outcome (Edeh et al., 2020).

Studies that discuss technology adoption using an environmental framework using the TOE framework include: (1) government support: some research findings show that this has a positive effect (Hasani et al., 2017; Qashou \& Saleh, 2018), while the findings of other researchers indicate that it has no effect (Asiaei \& Nor , 2019; Wong et al., 2020); and (2) in terms of broadband, some researchers' findings show a positive effect (Gareeb \& Naicker, 2015; Hasbi, 2020; Takieddine \& Sun, 2015), while others show no effect (Bertschek et al., 2013; Colombo et al., 2013).

The results of research related to MFIs conducted by Ammar \& Ahmed (2016) indicate that most MFI customers in Sudan have a strong inclination to use m-banking, which is influenced by performance expectations and business expectations as the main determinants. On the supply side, in an organizational context, a study conducted by Muriuki (2009) and Ammar \& Ahmed (2016) showed that MFIs with strong support and commitment to e-banking from top management were more likely to adopt e-banking, and also that MFIs that had requested Information and Communication Technology (ICT) and business resources for e-banking adoption had a better chance of adopting e-banking.

To the knowledge of the researchers, this research is a novel study of the factors that influence cooperative institutions facing the Covid-19 pandemic in terms of technology adoption by integrating the Technology-
Organization-Environment (TOE) and Unified Theory of Acceptance and Use of Technology (UTAUT) frameworks, which bridges previous research. This is because the majority of previous research and literature has been on technology adoption decisions by SMEs, companies, bank customers, and MFI customers. Empirical studies on microfinance sector technology adoption decisions by MFIs are minimal, although there is some literature on m-banking adoption decisions by MFIs (Ammar \& Ahmed, 2016) and e-banking adoption decisions by MFIs (Muriuki, 2009 in Ammar \& Ahmed, 2016). The results of previous studies exhibit research gaps that need to be re-examined by integrating the TOE and UTAUT frameworks, providing a theoretical basis for assessing the technological, organizational, and environmental frameworks which influence institutional/company decisions regarding the adoption of technology, especially in the era of the Covid-19 pandemic, in order to stay afloat.

Several researchers describe the TechnologyOrganization-Environment (TOE) framework to explain the innovation process at the enterprise level (Martins et al., 2016). This framework has consistent and substantial empirical support in providing a basis for the analysis of factors that influence a company's adoption decisions in relation to innovation (Wei et al., 2015) and is one of the frameworks that recognize non-determinism concerning technology adoption (Awa, Ukoha, et al., 2017). The TOE framework explains the technological innovation process at the enterprise level. Bose \& Luo (2011) argue that the TOE framework does not provide a concrete model to describe the factors that influence the perspective of the stages in technological innovation adoption. So, other researchers recommend using an integrative approach that combines more than one theory (Martins et al., 2016). Another researcher proposes that technology will enrich the environmental context of the TOE framework (Martins et al., 2016), while UTAUT brings together some important factors related to the consideration of the importance of using technology, especially in the organizational context (Darmansyah et al., 2020). The significance of this research is to fill this gap so that it can identify the factors that influence cooperatives to survive in the face of the Covid-19 pandemic.

\section{METHODOLOGY}

This research was carried out using qualitative and quantitative methods, by integrating the TechnologyOrganization-Environment (TOE) and Unified Theory of Acceptance and Use of Technology (UTAUT) frameworks. It started with semi-structured questions addressed to the managers of cooperative financial institutions; then a quantitative study was carried out, ending with conclusions and recommendations. The variables used in this study are the technology context, integrating the Unified Theory of Acceptance and Use of Technology (UTAUT) framework using: (1) performance expectations, (2) hedonic motivation 
and (3) business prospects. One other technological context is (4) perceived benefits. The organizational framework uses the TOE framework: (1) top management support, (2) costs and (3) innovation. In addition, the environmental framework uses the TOE framework: (1) government support and (2) broadband. The population in this study was 4,090 active cooperatives in Bali in 2020. The sampling technique used the stratified purposive sampling method, so the sample of this study was 266 managers and chairpersons of the cooperatives. The analysis of the data used in this study is a multivariate analysis tested by Partial Least Square (PLS).

\section{FINDINGS AND CONCLUSIONS}

Research findings, based on the unstructured interviews with the managers and chairpersons of cooperatives carried out in the face of the new era of life with the Covid-19 pandemic, cover the following: (1) splitting employees' operations, (2) carrying out credit restructuring, (3) relaxing credit, (4) applying for funding assistance through the Cooperatives and Micro, Small and Medium sized Enterprises and Revolving Fund Management Agency (LPDB-KUMKM), (5) obtaining loan assistance from the government (LPDB-KUMKM), (6) enforcing the use of technology in operational services to comply with health protocols, (7) expanding or improving operational service channels using existing technology to be able to meet community needs, and (8) promoting online transaction services used by cooperative members.

The Managers and Chairpersons of the Cooperatives explained that the use of technology in cooperative operational services provided for members enabled the institution to survive in the current Covid-19 pandemic. Members' needs can be met through financial service facilities such as mobile technology provided by the cooperatives. The members who have businesses in the MSME sector help make sales even though they are not as optimal as before the Covid-19 pandemic. The cash flow of the cooperative is within safe limits. The cooperatives receive deposits from the community and then distribute them to the cooperative members. Bringing together deposit owners and members who apply for credit creates a sense of trust in the institution. The members have a sense of responsibility for credit applications received by the cooperatives. Meanwhile, cooperatives that have not used technology in operational services to members have experienced difficulties maintaining their cash flow and cooperative liquidity.

Managers and administrators of cooperatives stated that the use of technology had certain performance expectations. Just over half $(53.8 \%)$ said they were able to increase business productivity, while 83.8 percent of the cooperatives stated that they maintained cooperative liquidity by using technology. As regards their business prospects, 98 percent of the cooperatives stated that the use of technology in operational services had created new opportunities, while
61.5 percent stated that operational services using technology helped cooperatives to provide solutions during the pandemic era and increase cooperative business productivity, resulting in greater work effectiveness and efficiency compared to using the manual method. Cooperative operations using technology were supported by employee capability (82 percent), assisted in cooperative marketing (53.8 percent), and assisted in the development of businesses owned by cooperative members, especially during the pandemic (92.3 percent).

Cost is not an obstacle for cooperatives in developing operational services using technology because the positive impacts obtained are greater, including time efficiency, transparency of financial transactions, minimizing abuse of authority, ease in controlling cooperative financial transactions, ease in compiling financial reports, member trust in institutions, maintaining cooperative liquidity, increased cooperative assets, and an improved image of cooperatives in the community. A manager also explained that he was very grateful because cooperatives could use technology in operational services, earning them the trust of the Supreme Audit Agency and the Financial Services Authority, which recognised them to be the only cooperatives in Bali that distribute People's Business Credit, with the result that the cooperatives can survive and help the businesses of their members by channelling credit through smartphones. This was able to happen thanks to the support of top management who innovated, and adjusted broadband needs in cooperatives, and due to the hedonic motivation of the institution, so that the cooperative continues to exist and maintain an encouraging daily cash flow.

Of the cooperatives included in this study, 76.9 percent stated that they were still able to provide services to their members during the Covid-19 pandemic by using technologybased operational services. According to 80 percent, using technology for operational services enabled the cooperative to survive during the pandemic. Moreover, 69 percent of the managers and cooperative administrators said that the use of technology for operational services improved the operational quality of the cooperatives, while 61.5 percent stated that cooperative operational services using technology were delivered to help the business operations of the cooperative's members. Overall therefore, the cooperatives stated that they had benefited from using technology services in operational services during the pandemic era.

The vast majority (99 percent) of top management support considered that it was important for cooperatives to apply technology in operational services. Just over two thirds (69.2 percent) stated that management and administrators encourage technological innovation, while 53.8 percent said that management and administrators assign special employees in the IT field as well as budgeting finances and preparing infrastructure to innovate technology. With government regulations regarding health protocols during the 
pandemic, 84 percent of cooperatives stated that they created new financing in cooperative services such as purchasing masks, hand sanitizers and disinfectants. Also 84 percent pointed out that if operational services utilised technology, this would reduce operational costs.

According to 69.2 percent of the cooperatives, in order to survive they need to use technology for operational services. For their cooperative to survive during the pandemic era, 53.8 percent increased the types of technology services used to support operational services, and 53.8 percent increased cooperation with other financial institutions. Factors that affected the implementation of cooperative operational services using technology were the availability of internet networks according to 53.8 percent of the cooperatives, internet speed (69.2 percent) and a stable internet connection (76.9 percent). As regards government involvement, 30.8 percent of the cooperatives said that the government pays attention to the availability of internet network speeds around the cooperative's working area, 90.8 percent stated that the government has provided revolving fund assistance to cooperatives during the pandemic era, and 53.9 percent said that the government provides incentives to cooperatives when developing technological innovations in operational services using technology.

Several efforts made by cooperatives related to the use of technology in the era of the Covid-19 pandemic include: (1) developing and improving the technology system used; (2) socializing applications owned by cooperatives so that members understand the benefits; (3) integrating all applications into the core system; (4) developing operational systems with a letter of agreement with the developer programmer; (5) developing various technology-based service innovations; (6) striving for product innovation services in the use of technology; (7) assisting members in marketing business products and services owned by members; (8) creating non-cash payments; and (9) being selective in disbursing loans.

Meanwhile, cooperatives that have not used technology in operational services to members explained the difficulties in maintaining the cash flow of cooperative institutions and cooperative liquidity. The cooperative managers said that the reasons why some cooperatives have not used technology in operational services to members include: a lack of top management support, a lack of understanding by managers and administrators that implementing financial services using technology benefits the sustainability of the institution's operations, a lack of innovation to adjust to the impact of the Covid-19 pandemic, a lack of motivation to adapt to digital technology transformation as part of cooperative modernization, and a lack of employees who have an understanding of information and technology.

The constraints faced by cooperatives that have not used the core system were stated to be: that information will be late, operations are slow, bookkeeping is slow, decision making is slow, data access is slow, fraud is easy. Meanwhile, the benefits obtained by cooperatives using the core system include: it is easier for institutions to record and process transactions every day so that they are able to produce financial reports more quickly and with greater accuracy; it is easier to make transactions; operations can run faster; data is stored properly; information is served quickly; operator errors are reduced; data is integrated and easily accessible; cooperative financial accounting is organized and the process is very fast and very useful because it quickly retrieves the information needed; work becomes easier; human resources can be used more optimally; it facilitates greater financial transparency; it limits fraudulent transactions; bookkeeping reports are more accountable; efficiency, productivity and opportunities increase and, no less important, it is possible to serve all members more quickly, transparently and optimally.

In conclusion, it is seen that cooperatives' use of technology to deliver operational services in order to ensure the sustainability of the institution is influenced by top management support, performance expectations, hedonic motivation, perceived benefits, innovation and government support. The efforts made by cooperatives in Bali related to the use of technology in the era of the Covid-19 pandemic include: (1) developing and improving the technology system used; (2) socializing applications owned by cooperatives so that members understand the benefits; (3) integrating all applications into the core system; (4) developing operational systems with a letter of agreement with the developer programmer; (5) developing various technology-based service innovations; (6) striving for product innovation services in the use of technology; (7) assisting members in marketing products and business services owned by the members; (8) creating non-cash payments; and (9) being selective in disbursing loans.

\section{AUTHORS' CONTRIBUTIONS}

Our study offers several important contributions, firstly contributing to the literature in the field of microfinance institutions related to the identification of factors influencing cooperative survival during the Covid-19 pandemic by integrating the TOE and UTAUT frameworks to bridge the research gap. Second, to our knowledge, this study is the first to examine the decisions of managers of cooperative institutions to adopt technology by applying UTAUT2 theory. Third, assisting the Bali Provincial Office for Cooperatives, Small and Medium sized Enterprises as well as the Cooperatives, Small and Medium sized Enterprises in Regency/Municipalities in Bali to collect data on cooperatives using technology and identify factors that influence cooperatives' survival during the Covid-19 pandemic.

\section{ACKNOWLEDGMENTS}

Several parties contributed to the success of the findings in this study. The researchers would therefore like to thank 
the Head of the Bali Province Cooperatives and SMEs Office along with all the managers and cooperative managers who kindly agreed to be interviewed, and also thank the entire committee of The $5^{\text {th }}$ International Conference on Sustainable Innovation (ICoSI) 2020 Muhammadiyah University of Yogyakarta.

\section{REFERENCES}

[1] Addy, M., Adinyira, E., \& Ayarkwa, J. (2018). Antecedents of Building Information Modelling Adoption Among Quantity Surveyors in Ghana: An Application of A Technology Acceptance Model. Journal of Engineering, Design and Technology, 16(2), 313-326. DOI: https://doi.org/10.1108/JEDT-06-2017-0056

[2] Alkhater, N., Walters, R., \& Wills, G. (2018). An Empirical Study of Factors Influencing Cloud Adoption Among Private Sector Organisations. Telematics and Informatics, 35(1), 3854. DOI: https://doi.org/10.1016/j.tele.2017.09.017

[3] Ammar, A., \& Ahmed, E. M. (2016). Factors influencing Sudanese microfinance intention to adopt mobile banking. Cogent Business and Management, 3(1). DOI: https://doi.org/10.1080/23311975.2016.1154257

[4] Asiaei, A., \& Nor, N. Z. (2019). A Multifaceted Framework for Adoption of Cloud Computing in Malaysian SMEs. Journal of Science and Technology Policy Management, 10(3), 708750. DOI: https://doi.org/10.1108/JSTPM-05-2018-0053

[5] Awa, H. O., Ojiabo, O. U., \& Orokor, L. E. (2017). Integrated Technology-Organization-Environment (T-O-E) Taxonomies for Technology Adoption. Journal of Enterprise Information Management, 30(6), 893-921. https://doi.org/10.1108/JEIM03-2016-0079

[6] Awa, H. O., Ukoha, O., \& Igwe, S. R. (2017). Revisiting Technology-Organization-Environment (T-O-E) Theory for Enriched Applicability. Bottom Line, 30(1), 2-22. DOI: https://doi.org/10.1108/BL-12-2016-0044

[7] Ayaz, A., \& Yanartaş, M. (2020). An analysis on the unified theory of acceptance and use of technology theory (UTAUT): Acceptance of electronic document management system (EDMS). Computers in Human Behavior Reports, 2(September), 100032 .

DOI: https://doi.org/10.1016/j.chbr.2020.100032

[8] Baliprov. (2020). Pemprov Bali Terus Dukung UMKM Lokal di Masa Pandemi. Baliprov.Go.Id. baliprov.go.id

[9] Bartik, A. W., Bertrand, M., Cullen, Z., Glaeser, E. L., Luca, M., \& Stanton, C. (2020). The impact of COVID-19 on small business outcomes and expectations. Proceedings of the National Academy of Sciences of the United States of America, 117(30), 17656-17666. DOI: https://doi.org/10.1073/pnas.2006991117

[10] Bertschek, I., Cerquera, D., \& Klein, G. J. (2013). More bits more bucks? Measuring the impact of broadband internet on firm performance. Information Economics and Policy, 25(3), 190-203.

DOI: https://doi.org/10.1016/j.infoecopol.2012.11.002

[11] Bisnisbali.com. (2020). Dorong Koperasi " Go Digital ”, Diskop dan UMKM Denpasar Gelar Diklat IT. Bisnisbali.Com, November. http://bisnisbali.com/dorongkoperasi-go-digital-diskop-dan-umkm-denpasar-gelar-diklatit/

[12] Bose, R., \& Luo, X. (2011). Integrative Framework for Assessing Firms' Potential to Undertake Green IT Initiatives Via Virtualization - A Theoretical Perspective. Journal of Strategic Information Systems, 20(1), 38-54. DOI: https://doi.org/10.1016/j.jsis.2011.01.003

[13] Colombo, M. G., Croce, A., \& Grilli, L. (2013). ICT services and small businesses' productivity gains: An analysis of the adoption of broadband Internet technology. Information Economics and Policy, 25(3), 171-189. DOI: https://doi.org/10.1016/j.infoecopol.2012.11.001

[14] Darmansyah, Fianto, B. A., Hendratmi, A., \& Aziz, P. F. (2020). Factors Determining Behavioral Intentions to Use Islamic Financial Technology. Journal of Islamic Marketing. DOI: https://doi.org/10.1108/JIMA-12-2019-0252

[15] de Caro, F., Hirschmann, T. M., \& Verdonk, P. (2020). Returning to orthopaedic business as usual after COVID-19: strategies and options. Knee Surgery, Sports Traumatology, Arthroscopy, 28(6), 1699-1704. DOI: https://doi.org/10.1007/s00167-020-06031-3

[16] Edeh, J. N., Obodoechi, D. N., \& Ramos-Hidalgo, E. (2020). Effects of innovation strategies on export performance: New empirical evidence from developing market firms. Technological Forecasting and Social Change, 158(January), 120167. DOI: https://doi.org/10.1016/j.techfore.2020.120167

[17] El-Haddadeh, R. (2020). Digital Innovation Dynamics Influence on Organisational Adoption: The Case of Cloud Computing Services. Information Systems Frontiers, 22(4), 985-999. DOI: https://doi.org/10.1007/s10796-019-09912-2

[18] Fernandes, N. (2020). Economic effects of coronavirus outbreak ( COVID-19) on the world economy. IESE Business School Spain. SSRN Electronic Journal, ISSN 1556-5068, Elsevier BV, 0-29.

[19] Gareeb, P. P., \& Naicker, V. (2015). Determinants for South African SMEs to adopt broadband internet technologies. Electronic Journal of Information Systems in Developing Countries, 68, 1-24. DOI: https://doi.org/10.1002/j.16814835.2015.tb00491.x

[20] Ghobakhloo, M., Arias-Aranda, D., \& Benitez-Amado, J. (2011). Adoption of e-commerce applications in SMEs. In Industrial Management and Data Systems (Vol. 111, Issue 8). DOI: https://doi.org/10.1108/02635571111170785

[21] Ghobakhloo, M., \& Ching, N. T. (2019). Adoption of digital technologies of smart manufacturing in SMEs. Journal of Industrial Information Integration, 16(January), 100107. DOI: https://doi.org/10.1016/j.jii.2019.100107

[22] Gutierrez, A., Boukrami, E., \& Lumsden, R. (2015). Technological, organisational and environmental factors influencing managers' decision to adopt cloud computing in the UK. Journal of Enterprise Information Management, 28(6), 788-807. DOI: https://doi.org/10.1108/JEIM-01-20150001

[23] Hasani, T., Bojei, J., \& Dehghantanha, A. (2017). Investigating the antecedents to the adoption of SCRM technologies by start-up companies. Telematics and Informatics, 34(5), 655675. DOI: https://doi.org/10.1016/j.tele.2016.12.004

[24] Hasbi, M. (2020). Impact of very high-speed broadband on company creation and entrepreneurship: Empirical Evidence. Telecommunications Policy, 44(3), 1-21. DOI:https://doi.org/10.1016/j.telpol.2019.101873

[25] Hoque, M. R., Saif, A. N. M., AlBar, A. M., \& Bao, Y. (2016). Adoption of information and communication technology for development: A case study of small and medium enterprises in Bangladesh. Information Development, 32(4), 986-1000. DOI: https://doi.org/10.1177/0266666915578202

[26] Huesig, S., \& Endres, H. (2019). Exploring the digital innovation process: The role of functionality for the adoption of innovation management software by innovation managers. European Journal of Innovation Management, 22(2), 302 314. DOI: https://doi.org/10.1108/EJIM-02-2018-0051

[27] Ilin, V., Ivetić, J., \& Simić, D. (2017). Understanding the determinants of e-business adoption in ERP-enabled firms and non-ERP-enabled firms: A case study of the Western Balkan Peninsula. Technological Forecasting and Social 
Change, 125(August), 206-223. DOI: htt ps://doi.org/10.1016/j.techfore.2017.07.025

[28] Janssens, W., Pradhan, M., de Groot, R., Sidze, E., Donfouet, H. P. P., \& Abajobir, A. (2021). The short-term economic effects of COVID-19 on low-income households in rural Kenya: An analysis using weekly financial household data. World Development, 138, 105280. DOI: https://doi.org/10.1016/j.worlddev.2020.105280

[29] Kováŕíková, L., Grosová, S., \& Baran, D. (2017). Critical Factors Impacting the Adoption of Foresight by Companies. In Foresight (Vol. 19, Issue 6, pp. 541-558). DOI: https://doi.org/10.1108/FS-02-2017-0009

[30] Kumar, A., \& Kalse, A. (2021). Usage and Adoption of Artificial Intelligence in SMEs. Materials Today: Proceedings.

DOI: https://doi.org/10.1016/j.matpr.2021.01.595

[31] Larsson, S., \& Gustavsson, S. (2020). Marketing Innovation for SMEs during COVID-19 Pandemic. Lulea University of Technology.

[32] Le, A. T. P., Kunasekaran, P., Rasoolimanesh, S. M., AriRagavan, N., \& Thomas, T. K. (2021). Investigating the determinants and process of destination management system (DMS) implementation. Journal of Organizational Change Management. DOI: https://doi.org/10.1108/JOCM-11-20200352

[33] Lian, J. W., Yen, D. C., \& Wang, Y. T. (2014). An exploratory study to understand the critical factors affecting the decision to adopt cloud computing in Taiwan hospital. International Journal of Information Management, 34(1), 28-36. DOI: https://doi.org/10.1016/j.ijinfomgt.2013.09.004

[34] Maduku, D. K., Mpinganjira, M., \& Duh, H. (2016). Understanding mobile marketing adoption intention by South African SMEs: A multi-perspective framework. International Journal of Information Management, 36(5), 711-723. https://doi.org/10.1016/j.ijinfomgt.2016.04.018

[35] Martins, R., Oliveira, T., \& Thomas, M. A. (2016). An Empirical Analysis to Assess The Determinants of SaaS Diffusion in Firms. Computers in Human Behavior, 62, 1933. DOI: https://doi.org/10.1016/j.chb.2016.03.049

[36] Nusabali.com. (2020). Koperasi Diajak Terapkan Digitalisasi. Nusabali.Com

https://www.nusabali.com/berita/82842/koperasi-diajakterapkan-digitalisasi

[37] Ooi, K., Lee, V., Tan, G. W., Hew, T., \& Hew, J. (2018). Cloud Computing in Manufacturing: The Next Industrial Revolution in Malaysia? Expert Systems With Applications, 93, 376-394.

DOI: https://doi.org/10.1016/j.eswa.2017.10.009

[38] Osakwe, C. N., Chovancová, M., \& Agu, M. (2015). Can micro-enterprises leverage on the adoption of corporate websites to bolster their brand visibility? Examining salient adoption issues in Nigeria. Information Development, 32(4), 904-919. DOI: https://doi.org/10.1177/0266666915573551

[39] Pemerintah Provinsi Bali. (2020). Terdampak Pandemi, Gubernur Koster Gelontorkan Stimulus untuk Usaha Koperasi. Baliprov.Go.Id. https://www.baliprov.go.id/web/terdampak-pandemigubernur-koster-gelontorkan-stimulus-untuk-usaha-koperasi/

[40] Qalati, S. A., Yuan, L. W., Khan, M. A. S., \& Anwar, F. (2021). A Mediated Model On The Adoption Of Social Media And SMEs' Performance In Developing Countries. Technology in Society, 64(July 2020), 101513. DOI: https://doi.org/10.1016/j.techsoc.2020.101513

[41] Qashou, A., \& Saleh, Y. (2018). E-marketing implementation in small and medium-sized restaurants in Palestine. Arab Economic and Business Journal, 13(2), 93-110. DOI: https://doi.org/10.1016/j.aebj.2018.07.001
[42] Ridwansah, D. (2020). Digital Banking, Solusi Perbankan Layani Nasabah di Era Pendemi Covid. JawaPos.Com, 2019_ 2020.

https://www.jawapos.com/ekonomi/16/05/2020/digitalbanking-solusi-perbankan-layani-nasabah-di-era-pendemicovid/

[43] Rohmat. (2020). Masa Pandemi , Koperasi dan UMKM Diharapkan Bangun Pasar Melalui Digitalisasi. Balinesia.Id. https://balinesia.id/read/masa-pandemi-koperasi-dan-umkmdiharapkan-bangun-pasar-melalui-digitalisasi

[44] Rustam, B. R. (2020). COVID-19 dan Risiko Operasional Bank. Analisis.Kontan.Co.Id, April, 1-3. https://analisis.kontan.co.id/news/covid-19-dan-risikooperasional-bank

[45] Santoso, Y. I., \& Laoli, N. (2020). Menghitung dampak Covid19 terhadap usaha Hingga UMKM. Kontan.Co.Id, April. https://nasional.kontan.co.id/news/menghitung-dampakcovid-19-terhadap-dunia-usaha-hingga-umkm

[46] Shereen, M. A., Khan, S., Kazmi, A., Bashir, N., \& Siddique, R. (2020). COVID-19 infection: Origin, transmission, and characteristics of human coronaviruses. Journal of Advanced Research, 24, 91-98. https://doi.org/10.1016/j.jare.2020.03.005

[47] Sivathanu, B. (2019). Adoption of industrial IoT (IIoT) in autocomponent manufacturing SMEs in India. Information Resources Management Journal, 32(2), 52-75. DOI: https://doi.org/10.4018/IRMJ.2019040103

[48] Takieddine, S., \& Sun, J. (2015). Internet banking diffusion: A country-level analysis. Electronic Commerce Research and Applications, 14(5), 361-371. DOI: https://doi.org/10.1016/j.elerap.2015.06.001

[49] Wei, J., Lowry, P. B., \& Seedorf, S. (2015). The Assimilation of RFID Technology by Chinese Companies: A Technology Diffusion Perspective. Information and Management, 52(6), 628-642. https://doi.org/10.1016/j.im.2015.05.001

[50] Wiratmini, N. P. E. (2021). Jumlah Penduduk Bali 4,32 Juta, Mayoritas Usia Produktif. Bali.Bisnis.Com.

[51] Wong, L. W., Leong, L. Y., Hew, J. J., Tan, G. W. H., \& Ooi, K. B. (2020). Time to Seize The Digital Evolution: Adoption of Blockchain In Operations and Supply Chain Management Among Malaysian SMEs. International Journal of Information Management, 52(August 2019), 101997. DOI: https://doi.org/10.1016/j.ijinfomgt.2019.08.005

[52] Zaazou, Z. A., \& Abdou, D. S. (2020). Egyptian Small and Medium Sized Enterprises 'Battle Against COVID- 19 Pandemic: March - July 2020. Journal of Humanities and Applied Social Sciences, July. DOI: https://doi.org/10.1108/JHASS-09-2020-0161

[53] Zetterli, P. (2020). Four Ways Microfinance Institutions Are Responding to COVID-19 (Issue August 2020). https://www.cgap.org/blog/four-ways-microfinanceinstitutions-are-responding-covid-19

[54] Zheng, C., \& Zhang, J. (2021). The impact of COVID-19 on the efficiency of microfinance institutions. International Review of Economics and Finance, 71, 407-423. DOI: https://doi.org/10.1016/j.iref.2020.09.016

[55] Zuiderwijk, A., Janssen, M., \& Dwivedi, Y. K. (2015). Acceptance and use predictors of open data technologies: Drawing upon the unified theory of acceptance and use of technology. Government Information Quarterly, 32(4), 429440. DOI: https://doi.org/10.1016/j.giq.2015.09.005 